\title{
Annexin II regulates fibrin homeostasis and neoangiogenesis in vivo
}

\author{
Qi Ling, ${ }^{1}$ Andrew T. Jacovina, ${ }^{1}$ Arunkumar Deora, ${ }^{1}$ Maria Febbraio, ${ }^{2}$ Ronit Simantov, ${ }^{2}$ \\ Roy L. Silverstein, ${ }^{2}$ Barbara Hempstead, ${ }^{2}$ Willie H. Mark, ${ }^{3}$ and Katherine A. Hajjar ${ }^{1}$ \\ ${ }^{1}$ Department of Cell and Developmental Biology, and \\ ${ }^{2}$ Department of Medicine, Weill Medical College of Cornell University, New York, New York, USA \\ ${ }^{3}$ Developmental Biology Program, Sloan-Kettering Institute, Memorial Sloan-Kettering Cancer Center, New York, \\ New York, USA
}

\begin{abstract}
A central tenet of fibrinolysis is that tissue plasminogen activator-dependent ( $t$-PA- dependent) conversion of plasminogen to active plasmin requires the presence of the cofactor/substrate fibrin. However, previous in vitro studies have suggested that the endothelial cell surface protein annexin II can stimulate t-PA-mediated plasminogen activation in the complete absence of fibrin. Here, homozygous annexin II-null mice displayed deposition of fibrin in the microvasculature and incomplete clearance of injury-induced arterial thrombi. While these animals demonstrated normal lysis of a fibrin-containing plasma clot, t-PA-dependent plasmin generation at the endothelial cell surface was markedly deficient. Directed migration of annexin II-null endothelial cells through fibrin and collagen lattices in vitro was also reduced, and an annexin II peptide mimicking sequences necessary for t-PA binding blocked endothelial cell invasion of Matrigel implants in wild-type mice. In addition, annexin II-deficient mice displayed markedly diminished neovascularization of fibroblast growth factor-stimulated cornea and of oxygen-primed neonatal retina. Capillary sprouting from annexin II-deficient aortic ring explants was markedly reduced in association with severe impairment of activation of metalloproteinase- 9 and -13 . These data establish annexin II as a regulator of cell surface plasmin generation and reveal that impaired endothelial cell fibrinolytic activity constitutes a barrier to effective neoangiogenesis.
\end{abstract}

J. Clin. Invest. 113:38-48 (2004). doi:10.1172/JCI200419684.

\section{Introduction}

Endothelial cells, which line all blood vessels, play a critical role in hemostasis, the process by which blood fluidity and blood clotting are regulated $(1,2)$. Under resting conditions, the endothelium constitutes a mitotically quiescent, arborized conduit that supports the assembly of thromboresistance molecules. Indeed, the absence of endothelial cell-associated natural anticoagulant systems, such as the thrombin-thrombomodulin-protein $C$ activating system or the plateletmodulating CD39/ectoADPase, leads to intravascular clotting and tissue deposition of fibrin, even in the absence of overt prothrombotic stimuli $(3,4)$. Upon

Received for publication July 31, 2003, and accepted in revised form October 21, 2003.

Address correspondence to: Katherine A. Hajjar, Department of Cell and Developmental Biology, Weill Medical College of Cornell University, 1300 York Avenue - Box 45, New York, New York 10021, USA. Phone: (212) 746-2034; Fax: (212) 746-8809; E-mail: khajjar@med.cornell.edu.

Conflict of interest: The authors have declared that no conflict of interest exists.

Nonstandard abbreviations used: tissue plasminogen activator (t-PA); urokinase-type plasminogen activator (u-PA); matrix metalloproteinase (MMP); microvascular endothelial cell (CMEC); platelet-endothelial cell adhesion molecule (PECAM); endothelial cell basal medium (EBM); 3,3-diaminobenzidine tetrahydrochloride (DAB); inner limiting membrane (ILM); urokinase receptor (u-PAR). blood vessel injury, normal endothelial cells express the primary initiator of coagulation, tissue factor, whose ligation of factor VIIa initiates a cascade that culminates in thrombin-mediated polymerization of fibrin (5). Once the injured vessel has healed, the fibrinolytic system is activated, leading to plasmin-mediated dissolution of the thrombus, restoration of blood vessel patency, and renewal of blood flow (6).

The classical fibrinolytic system consists of sequential proteolytic events that, oriented on a fibrin surface, result in the generation of the $85-\mathrm{kDa}$ serine protease plasmin (7). The circulating zymogen plasminogen can be activated either by urokinase-type plasminogen activator (u-PA), a product of renal epithelial cells, monocyte/macrophages, and some tumor cells, or by tissue plasminogen activator ( $t-P A)$, an endothelial cell secretory product $(8-10)$. Fibrin augments the catalytic efficiency of t-PA-dependent plasminogen activation by about 500-fold (7). Plasmin cleaves cross-linked fibrin, a major constituent of both blood vessel thrombi and the provisional matrix that forms following tissue injury. Although $\mathrm{Plg}^{-1-}$ mice survive embryonic development, they are predisposed to severe thrombotic events and display extravascular fibrin deposition in liver, rectum, stomach, lung, pancreas, and thymus (11, 12). Similarly, mice deficient in both t-PA and u-PA show fibrin deposition in liver, intestine, gonads, and lung (13). Humans with plasminogen deficiency, as 
well as some strains of plasminogen-deficient mice, furthermore, develop "ligneous" conjunctivitis characterized by extravascular deposition of fibrin in the conjunctiva $(14,15)$. These studies clearly demonstrate that circulating and secreted fibrinolytic components are required for fibrin homeostasis.

Annexin II is a proposed endothelial cell coreceptor for plasminogen and t-PA (16). In vitro, this calciumregulated phospholipid-binding protein possesses t-PA cofactor activity and increases the catalytic efficiency $\left(\mathrm{k}_{\mathrm{cat}} / \mathrm{K}_{\mathrm{m}}\right)$ of t-PA-dependent plasmin generation by 60 fold $(16,17)$. In rats, pretreatment of the carotid artery with wild-type annexin II, but not a mutant form of the protein, prevents vessel thrombosis in response to oxidative injury with ferric chloride (18). Studies of humans with acute promyelocytic leukemia suggest that overexpression of annexin II on leukemic blast cells leads to dysregulated plasmin generation and a hyperfibrinolytic hemorrhagic state (19). These studies strongly suggest a regulatory role for annexin II in maintaining hemostatic balance.

In the present study, we have utilized targeted mutagenesis to analyze the physiologic role of annexin II. We show, for the first time to our knowledge, that annexin II regulates both microvascular fibrin homeostasis and macrovascular clearance of thrombi. In addition, we report that postnatal angiogenesis is markedly impaired in the absence of annexin II, due most likely to a failure to localize plasmin activity on the endothelial cell surface and a failure to activate selected matrix metalloproteinases (MMPs).

\section{Methods}

Generation of annexin II-null mice. For construction of the annexin II targeting vector, selectable neomycinresistance $\left(\mathrm{Neo}^{r}\right)$ and thymidine kinase (TK) genes within the plasmid pPNT were used. From a mouse genomic DNA library packaged in bacteriophage Lambda FIX II 129/SvJ (Stratagene, La Jolla, California, USA), two mouse cDNA probes specific for exons 2 and 3 , containing the translation start site, and for exon 5 were used to isolate two fragments encoding exons 1-4 and exons 2-5. A 2.2-kb fragment located $5^{\prime}$ of exon 3 and a second $4-\mathrm{kb}$ fragment located $3^{\prime}$ of exon 4 were isolated by restriction enzyme digestion and Southern blot analysis and were subcloned into pPNT in a transcription orientation opposite to that of the Neor cassette. The integrity of the targeting vector was verified by sequencing and the construct was linearized by NotI digestion and introduced into 129/SvJ ES cells (Genome Systems, St. Louis, Missouri, USA) by electroporation.

ES clones selected by resistance to G418 $(350 \mu \mathrm{g} / \mathrm{ml}$; Gibco BRL, Grand Island, New York, USA) and gancyclovir ( $2 \mu \mathrm{M}$; Roche Diagnostics, Indianapolis, Indiana, USA) were screened by Southern blot hybridization. Clones containing the disrupted annexin II allele were microinjected into blastocysts and implanted into the uteri of $\mathrm{C} 57 \mathrm{Bl} / 6 \mathrm{~J}$ pseudopregnant female mice.
Chimeric offspring identified by the presence of the agouti coat color were backcrossed to $\mathrm{C} 57 \mathrm{Bl} / 6 \mathrm{~J}$ mice. Germline transmission of the mutated allele was verified by Southern blot of genomic DNA obtained from tail tips. Heterozygous littermates were interbred to generate homozygous null progeny. All procedures were performed in accordance with Institutional Animal Care and Use Committee approval.

Southern, Northern, and Western blot analyses. For Southern blot analysis, cells or tail tips were incubated overnight in lysis buffer $(0.2 \% \mathrm{SDS}, 200 \mu \mathrm{g} / \mathrm{ml}$ proteinase $\mathrm{K}, 100 \mathrm{mM}$ Tris- $\mathrm{HCl}, \mathrm{pH} 8.5,200 \mathrm{mM} \mathrm{NaCl}$, and $5 \mathrm{mM}$ EDTA) at $56^{\circ} \mathrm{C}$ and were extracted with phenol-chloroform-isoamyl alcohol. Genomic DNA was fractionated by $0.45 \%$ agarose gel electrophoresis, transferred to Zeta-probe nylon membranes (Bio-Rad Laboratories, Hercules, California, USA), and hybridized with a random-primed ${ }^{32}$ P-labeled 800-bp 3' probe. This probe, representing sequences external to the targeting vector sequence, detected 18.8- and 16.4$\mathrm{kb}$ fragments of the wild-type and mutated alleles, respectively, thus identifying wild-type, heterozygous, and homozygous animals.

For Northern blot analysis, total RNA was extracted from tissues using TRIzol reagent (Invitrogen/Life Technologies, Carlsbad, California, USA), fractionated by formaldehyde-agarose gel electrophoresis, and transferred to Zeta-probe membranes (Bio-Rad Laboratories) by capillary transfer. The blots were hybridized with a human annexin II cDNA probe in QuikHyb buffer (Stratagene), washed, and exposed to x-ray film.

For Western blot analysis, tissues excised from euthanized mice were briefly washed with ice-cold PBS and homogenized by polytron in ice-cold lysis buffer $(20$ $\mathrm{mM}$ Tris- $\mathrm{HCl}, \mathrm{pH} 8.0,150 \mathrm{mM} \mathrm{NaCl}, 1 \%$ Triton X-100, and $1 \mathrm{mM}$ EDTA) containing protease inhibitors (1 $\mathrm{mM}$ phenylmethylsulfonyl fluoride, $0.5 \mu \mathrm{g} / \mathrm{ml}$ leupeptin, and $2 \mu \mathrm{g} / \mathrm{ml}$ aprotinin). After centrifugation $\left(12,000 \mathrm{~g}\right.$ for 10 minutes at $\left.4^{\circ} \mathrm{C}\right)$, soluble protein concentration was determined by BCA assay (Pierce Biotechnology, Rockford, Illinois, USA) and the extract resolved by $12 \%$ SDS-PAGE. Blots were probed with both monoclonal IgG (Zymed, South San Francisco, California, USA) and polyclonal IgG (a gift from Blake Pepinsky, Genetics Institute, Cambridge, Massachusetts, USA) and visualized by chemiluminescence (ECL; Amersham, Piscataway, New Jersey, USA).

Clot lysis studies. Plasma clotting was examined as described (20). For arterial thrombosis studies, the left carotid artery was isolated and placed within a miniature ultrasound flow probe (0.5VB; Transonic Systems, Ithaca, New York, USA) in mice anesthetized with Metofane (Schering-Plough, Kenilworth, New Jersey, USA) (21). Baseline blood flow was recorded for 1-2 minutes using a Transonic T106 flowmeter and WinDaq data acquisition software (DataQ Instruments, Akron, $\mathrm{OH}$ ). To induce arterial injury, a $0.5-\times 1-\mathrm{mm}$ strip of Whatman \#1 filter paper soaked with $10 \% \mathrm{FeCl}_{3}$ was applied to the dried adventitial surface of the artery for 3 
minutes. Following removal of the filter paper, carotid blood flow recording was resumed for 30 minutes.

Isolation and analysis of microvascular endothelial cells. Microvascular endothelial cells (CMECs) were isolated from hearts from neonatal P2-4 (day 2-4 posnatal age) pups, derived from homozygous matings (22). Cells exhibited typical cobblestone morphology (98\%), uptake of acetylated LDL (99\%), and cell surface expression of platelet-endothelial cell adhesion molecule (PECAM/CD31) (96\%). For proliferation assays, endothelial cells $\left(3 \times 10^{4} /\right.$ well $)$ were plated into 12 -well cluster dishes, harvested at 24,48 , and 72 hours by trypsinization, and enumerated with a hemocytometer by experimenters double-blinded to sample identity. Cells from passages three to five were used in all experiments. Plasmin generation experiments were conducted as previously described $(17,23)$.

For matrix invasion experiments, CMECs from wildtype and annexin II-null mice $\left(1 \times 10^{3}\right.$ cells per well $)$ were deposited in $0.25 \%$ FBS-containing medium upon 0.9 $\mathrm{cm}^{2}, 8-\mu \mathrm{m}$ pore filters (Transwell) left uncoated or coated with collagen I or fibrin. Lower chambers contained the same medium supplemented with VEGF-A (100 $\mathrm{ng} / \mathrm{ml}$; Sigma-Aldrich, St. Louis, Missouri, USA). After 16 hours, cells on the upper surface were scraped free, and the filters stained with hematoxylin. Cells migrating through the filter to its undersurface were enumerated by experimenters double-blinded to sample identity.

Aortic ring explants and MMP activity assays. Aortic ring segments from mice 8-12 weeks of age were cultured in three-dimensional collagen I gels using a modification of a skeletal muscle explant method $(24,25)$. Thoracic aortae were harvested, placed in sterile ice-cold serumfree endothelial cell basal medium (EBM) (Clonetics, San Diego, California, USA), sliced into $1.5-\mathrm{mm}$ ring segments, rinsed, and embedded in type I collagen (1.5 $\mathrm{mg} / \mathrm{ml}$; BD Biosciences, Bedford, Massachusetts, USA), which was then polymerized $\left(15\right.$ minutes at $\left.37^{\circ} \mathrm{C}\right)$, and incubated in EBM containing $20 \%$ FBS. The explant medium was changed every other day, and the microvessel outgrowth was assessed on day 6 by enumeration of the number of microvessels per explant and the number of microvessel branches per explant, and measurement of the maximal vessel length per explant. Emerging microvessel-like structures took up the endothelial cell marker acetylated low-density lipoprotein labeled with 1,1'-dioctadecyl-3,3,3', $3^{\prime}$ tetramethylindocarbocyanine perchlorate (Dil-Ac-LDL; Biomedical Technologies, Stoughton, Massachusetts, USA; $10 \mu \mathrm{g} / \mathrm{ml}$ for 18 hours at $37^{\circ} \mathrm{C}$ ), as judged by fluorescent microscopy using rhodamine excitation and emission filters.

For matrix metalloproteinase (MMP)-9 activity studies, aortic ring serum-free medium obtained after culture was analyzed using the MMP-9 Activity Assay System (Amersham Pharmacia Biotechnology, Piscataway, New Jersey, USA). For MMP-13 activation, 100- $\mu$ l aliquots of serum-free medium from parallel explants were incubated with $10 \mu \mathrm{l}$ sepharose-immobilized protein $\mathrm{G}$ (Pierce Biotechnology; $4^{\circ} \mathrm{C}$ for 1.5 hours), centrifuged
(500 $\mathrm{g}$ for 10 minutes at $4^{\circ} \mathrm{C}$ ), and analyzed by Western blot utilizing monoclonal anti-MMP-13 IgG (Oncogene Research Products, San Diego, California, USA) with ECL Plus chemiluminescence and Scion Image software.

Fibrin deposition. Mice were anesthetized with $5 \mathrm{mg}$ Avertin per $10 \mathrm{~g}$ body weight given intraperitoneally, anticoagulated by tail vein injection of $500 \mathrm{U}$ tissue culture-grade porcine intestinal heparin sodium (Sigma-Aldrich; $5 \mathrm{U} / \mu \mathrm{l}$ ), and perfused transcardially (80 $\mathrm{cm} \mathrm{H}_{2} \mathrm{O}$ pressure for 10 minutes) with ice-cold PBS via the left ventricle. Tissues were harvested, weighed, and stored frozen in liquid $\mathrm{N}_{2}$. Fibrin was extracted exactly as described $(26,27)$. Proteins were resolved by $7.5 \%$ SDS-PAGE and transferred to nitrocellulose membranes. Fibrin was analyzed using mouse anti-fibrin II IgG (NYB.T2G1; Accurate Chemical \& Scientific Corp., Westbury, New York, USA) with enhanced chemiluminescence (ECL; Amersham Pharmacia Biotechnology) and Scion Image software. For quantification, fibrin standards prepared by clotting a known amount of murine fibrinogen (SigmaAldrich) with an excess of thrombin in the absence of calcium were chosen such that experimental signal intensities fell within their linear range.

For immunohistochemical detection of cross-linked fibrin in murine tissues, tissues from wild-type and annexin II-null animals were fixed in 4\% paraformaldehyde (18 hours) and paraffin-embedded. Sections $6 \mu \mathrm{m}$ in thickness were stained with rabbit anti-human fibrin(ogen) IgG (Dako, Carpenteria, California, USA) $\left(21^{\circ} \mathrm{C}\right.$ for 1 hour; 1:1,000 dilution) and counterstained with hematoxylin. Nonimmune rabbit IgG served as a control. Specific antibody binding was detected with anti-rabbit ABC kit (Elite Vectastain; Vector Laboratories, Burlingame, California, USA) and was developed with 3,3-diaminobenzidine tetrahydrochloride (DAB).

Neoangiogenesis assays. For the Matrigel plug assay, tissue samples prepared as described (28) were harvested on day 12 , fixed in $4 \%$ paraformaldehyde, sectioned, stained with H\&E, and analyzed. Endothelial cells were enumerated both manually and using Metamorph image analysis software following staining with horseradish peroxidase-coupled anti-human vWF $\left(21^{\circ} \mathrm{C}\right.$ for 1 hour; 1:100 dilution; Dako).

For corneal pocket angiogenesis, wild-type and annexin II-null littermates were anesthetized with Avertin $(5 \mathrm{mg} / 10 \mathrm{~g}$ body weight, intraperitoneally), and pellets containing 0-50 ng of bFGF (Sigma-Aldrich) implanted in the cornea $1-1.2 \mathrm{~mm}$ from the limbus as described (29). After 5 days, eyes were examined and photographed (Sony DKC-5000 digital camera; Sony Corp., Tokyo, Japan). The area of neovascularization (angiogenesis index) was calculated by measuring maximal vessel length from the limbus toward the pellet and the number of clock hours of neovascularization (30). Corneas were dissected free from surrounding ocular tissues, snap-frozen in Tissue-Tek embedding medium (OCT; Sakura Finetek, Torrance, California, USA), and sectioned. Sections were incubated sequen- 
tially with rabbit anti-human fibrin(ogen) IgG (1:3,000 dilution; 1 hour at $21^{\circ} \mathrm{C}$; Dako) and rat anti-mouse CD31 IgG (1:500 dilution; 1 hour at $21^{\circ} \mathrm{C}$; PharMingen, BD Biosciences, Bedford, Massachusetts, USA). Specific antibody binding for CD31 and fibrin was detected with the $\mathrm{ABC}-\mathrm{DAB}$ and Vector Blue Alkaline Phosphatase kits (Vector Laboratories), respectively.

For the study of oxygen-induced retinopathy, P7 (postnatal day 7) litters and mothers were placed in a sealed chamber containing bedding, food, water, and continuous-flow $75 \% \mathrm{O}_{2} / 25 \% \mathrm{~N}_{2}$ for 5 days and then were returned to room air (31). Control age-matched litters and their mothers were caged under identical conditions with continuous-flow room air for 5 days. P17 (postnatal day 17) pups were anesthetized with $5 \mathrm{mg}$ Nembutol given intraperitoneally, the chest cavity was opened, and the descending aorta was clamped. FITC-Dextran (FD2000S; $1 \mathrm{ml}$ of 2,000-kDa, $50 \mathrm{mg} / \mathrm{ml}$ in PBS; SigmaAldrich) was infused transcardially ( $1 \mathrm{ml}$ over $10 \mathrm{~min}$ utes) via the left ventricle and allowed to exit via the punctured right atrium. One eye was fixed $(3.7 \%$ formaldehyde; 18 hours at $4^{\circ} \mathrm{C}$ ) for paraffin embedding, $\mathrm{H} \& \mathrm{E}$ staining, and enumeration of neovascular tufts and nuclei. The second was fixed $(0.125 \%$ glutaraldehyde; $21^{\circ} \mathrm{C}$ for 1 hour), after which the retina was dissected free, mounted in Vector Shield (Vector Laboratories), and examined by fluorescence microscopy (31).

\section{Results}

Annexin II-null mice. For inactivation of the annexin II gene, exons 3 and 4 were replaced with a cassette containing neomycin phosphotransferase (which confers $\mathrm{NeO}^{r}$ ) driven by the phosphoglucokinase promoter (Figure 1a). The targeting construct was introduced into $129 /$ SvJ ES cells by electroporation, and resistant colonies were selected with G418 and gancyclovir. Eight homologously targeted clones were identified out of 182 clones screened. Three independently and correctly targeted clones were microinjected into blastocysts and implanted into the uteri of 12 pseudopregnant $\mathrm{C} 57 \mathrm{Bl} / 6$ female mice. The resulting chimeras were mated to $\mathrm{C} 57 \mathrm{Bl} / 6$ animals and their offspring were genotyped by Southern blot analysis of DNA obtained from tail tips to determine germline transmission of the targeted allele (Figure 1b). By Northern blot analysis, annexin II mRNA from wild-type animals was strongly expressed in multiple tissues, including lung and heart, but was reduced in heterozygous animals (Figure 1c). Annexin II-null animals displayed lesser amounts of slightly more rapidly migrating annexin II mRNA, most likely because the targeting vector retained the transcription start site in exon 1 even though the translation start site in exon 3 had been eliminated. Western blot analysis using monoclonal and polyclonal IgG directed against annexin II (Figure $1, \mathrm{~d}$ and e) verified the absence of immunodetectable antigen in multiple annexin II-null tissues. Examination of tissue sections revealed anti-annexin II immunostaining of vascular endothelial cells in a wide range of tissues including liver, lung, and kidney from wild-type but not annexin II-null mice (not shown).

Intercrossing by heterozygous mating revealed the expected Mendelian ratios of genotype and gender. Like wild-type controls, homozygous null animals survived for at least 26 months. Mice resulting from six backcrosses to a pure C57Bl/ 6 background were also viable. In addition, matings between homozygous deficient animals and heterozygous animals produced normal litter sizes, indicating that annexin II-null animals of both sexes were fertile. Assessment of body mass in littermate pairs and backcrossed wild-type and annexin II-null animals fed ad libitum from 2 through 12 months of age revealed a $10-13 \%$ reduction in weight in the knockout animals $(29.9 \pm 1.1$ vs. $26.1 \pm 1.0 \mathrm{~g}$, mean $\pm \mathrm{SE}$, $n=7, P<0.01$ for females, and $37.6 \pm 1.2$ vs. $33.6 \pm 0.7 \mathrm{~g}$, mean \pm SE, $n=7, P<0.01$ for males), even though their food intake did not differ. All subsequent studies were performed with animals derived from two independent ES clones using either littermate controls or animals derived from at least six backcrossed generations.
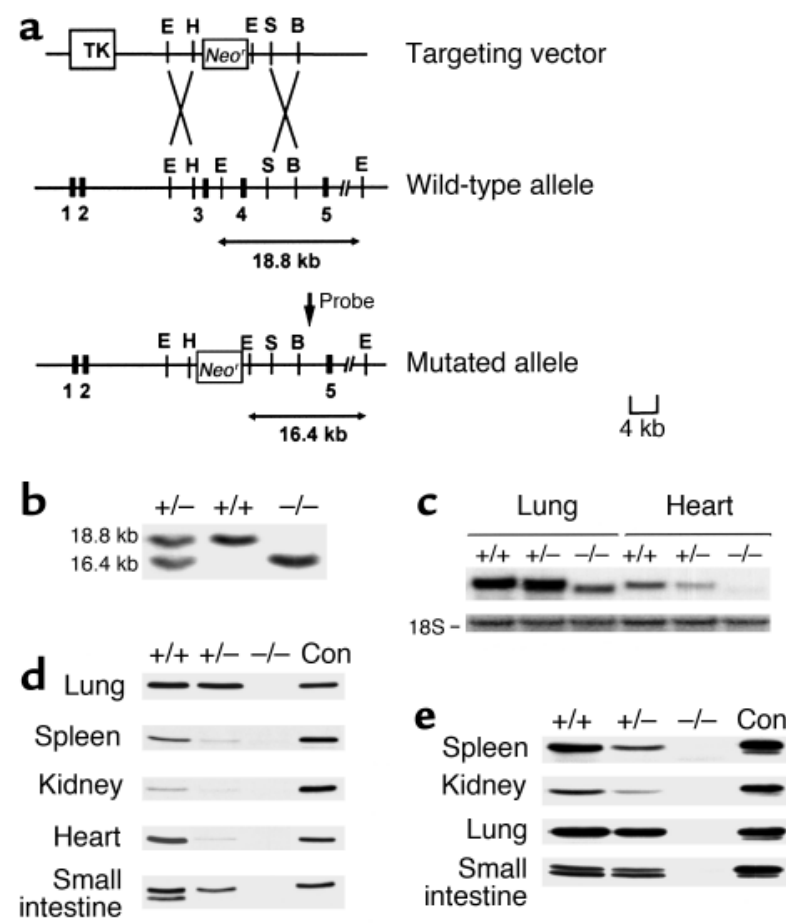

\section{Figure 1}

Generation of annexin II-null mice. (a) Genomic organization of the wild-type and targeted alleles after homologous recombination. The location of the probe used in Southern blotting is shown (arrow), as well as the sizes of EcoRI fragments identified for wild-type and mutant alleles (double headed arrows). Numerals 1-5 refer to exons 1-5. E, EcoRI; H, HindIII; S, Spell; B, Blinl. (b) Southern blot analysis of DNA obtained from tail tips. Fragments corresponding to wildtype $(18.8 \mathrm{~kb})$ and targeted $(16.4 \mathrm{~kb})$ alleles are shown. (c) Northern blot analysis of total RNA from lung and heart. RNA loading was monitored by ethidium bromide staining of RNA. (d and $\mathbf{e}$ ) Western blots utilizing monoclonal (d) and polyclonal (e) IgG directed against human annexin II. Protein expression for all three genotypes is shown. Con, control. 


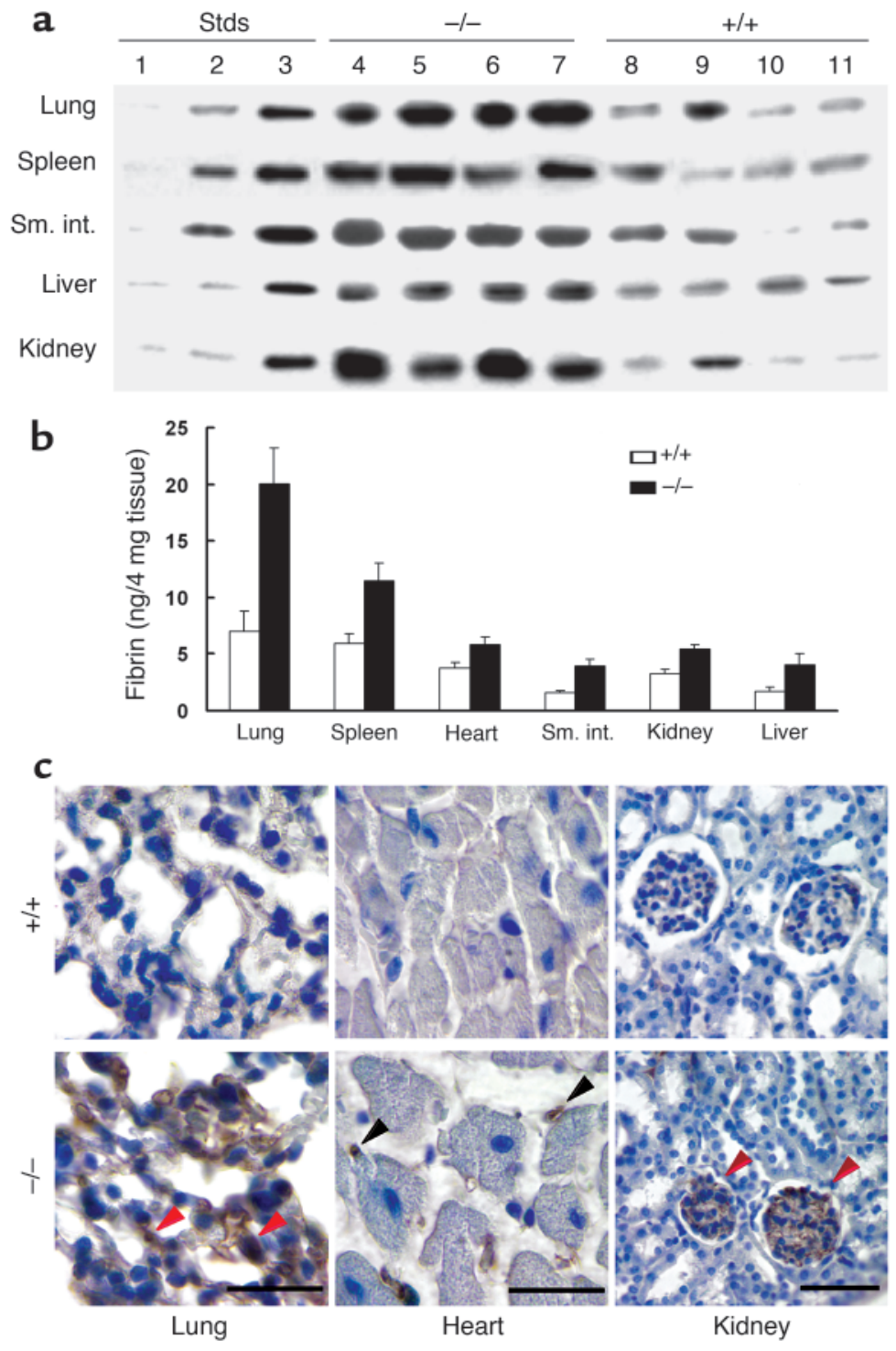

\begin{abstract}
Figure 2
Fibrin deposition. (a) Western blot analysis of five tissues showing mouse fibrin standards (Stds) in lanes 1-3 (2, 5, and $10 \mathrm{ng}$ for lung, spleen, and small intestine [Sm. int.], and 1, 2, and $5 \mathrm{ng}$ for liver and kidney). Samples from four separate annexin II-null and wild-type mice are shown in lanes 4-7 and 8-11, respectively. (b) Quantitative analysis of combined fibrin deposition data (mean $\pm \mathrm{SE}, n=4$ experiments). (c) Immunohistochemical analysis of wildtype and annexin II-null lung, myocardium, and kidney showing fibrin deposition in renal glomeruli (red arrowheads), myocardial capillaries (black arrowheads), and alveolar capillaries (red arrowheads). Scale bars indicate $0.05 \mathrm{~mm}$ (kidney) and $0.025 \mathrm{~mm}$ (heart and lung).
\end{abstract}

To assess the fluid-phase components of the fibrinolytic system, clot lysis profiles were studied in wild-type and annexin IInull mice (Figure 3a). We found no differences in mean clotting time of plasma from annexin II-replete mice ( $4.30 \pm 0.33 \mathrm{~min}$ utes, mean $\pm \mathrm{SE}, n=11$ ) versus plasma from annexin II-deficient mice $(4.55 \pm 0.95 \mathrm{~min}-$ utes, mean $\pm \mathrm{SE}, n=11)$. Similarly, neither the time to half-maximal clot lysis $(12.8 \pm 0.63$ vs. $12.3 \pm 0.57$ minutes, mean \pm SE, $n=11$ ) nor the extent of clot lysis in the presence of t-PA differed between the two groups. These data indicated that the plasma components of t-PA-dependent fibrinolytic activity functioned identically in wild-type and annexin II-null animals.

We next examined vascular fibrinolytic function (Figure 3, b-d). Acute carotid artery thrombosis was induced by the application of $\mathrm{FeCl}_{3}$ to the adventitial arterial surface in sexmatched littermate pairs. Baseline carotid flow rates were not statistically different between wild-type and annexin II-null ani-

Fibrinolytic function. Accumulation of intra- and extravascular fibrin is a hallmark of complete plasminogen or plasminogen activator deficiency in the mouse (11-13). Similarly, Western blot analysis of annexin II-null tissues revealed significantly higher levels of cross-linked fibrin compared with that of wild-type controls (Figure 2a). Quantification of band intensity revealed 1.5- to 2.9-fold increases in fibrin in lung, spleen, small intestine, liver, heart, and kidney from 2-month-old annexin II-null mice compared with wild-type controls (Figure 2b). Histochemistry of fixed, paraffin-embedded sections of the same tissues revealed anti-fibrin (ogen) cross-reactive material within pulmonary alveolar and myocardial capillaries, as well as renal glomeruli, while the same tissues from wild-type mice failed to show comparable staining (Figure 2c). These data reveal microvascular fibrin accumulation in annexin II-deficient mice and suggest a regulatory role for annexin II in baseline fibrinolytic surveillance. mals $(1.21 \pm 0.10$ vs. $1.40 \pm 0.14 \mathrm{ml} / \mathrm{min}$, respectively, mean $\pm \mathrm{SE}, n=12$ ). However, while thrombosis was observed in only 6 of 13 wild-type controls (46\%), 11 of 12 knockout animals (92\%) developed visible thrombi following application of $\mathrm{FeCl}_{3}$. Three null (27\%) but no wild-type mice, furthermore, experienced complete arterial occlusion with no recovery of blood flow at all (Figure $3 \mathrm{~b}$ ). The maximal degree of vessel occlusion was $31.3 \% \pm 11.6 \%$ and $78.2 \% \pm 8.9 \%$ (mean \pm SE, $n=12$ ) for wild-type and annexin II-null animals, respectively (Figure 3c). In addition, mean blood flow recovery after 30 minutes was $81.4 \% \pm 6.4 \%$ and $38.4 \% \pm 11.9 \%$ (mean \pm SE, $n=11$ ) of initial baseline flow for wild-type and annexin II-null animals, respectively (Figure 3d). These data indicate that annexin II deficiency is associated with impaired clearance of acute arterial thrombi.

Endothelial cell function. We studied the properties of microvascular endothelial cells isolated from wild-type and annexin II-deficient mice (Figure 4). The two cell types showed no differences in morphology, rates of pro- 

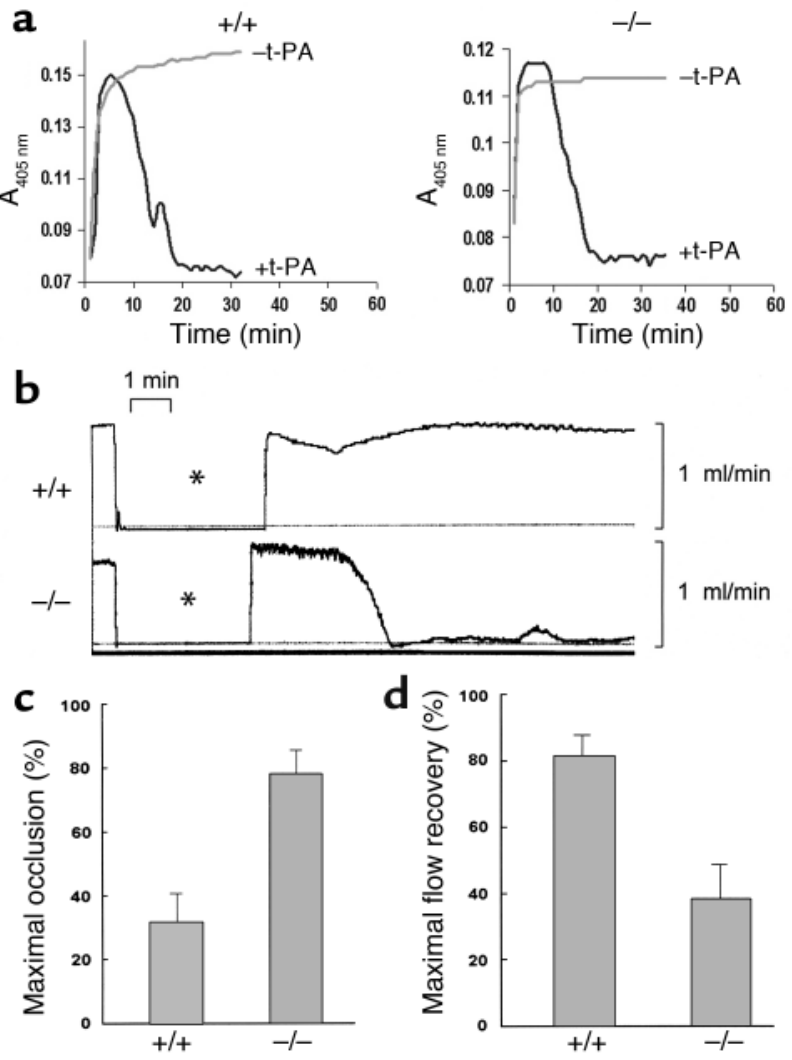

liferation or apoptosis, uptake of acetylated low density lipoprotein, or expression of PECAM/CD31. In addition, there was no difference in endothelial cell motility, as both cell types migrated through uncoated $8-\mu \mathrm{m}$ pore filters in response to VEGF-A (not shown). However, compared with that of wild-type cells, migration of annexin II-deficient cells through both collagen I and fibrin matrices was reduced by $45-50 \%$ (367 \pm 73 vs $186 \pm 40$ and $242 \pm 21$ vs $135 \pm 8$ cells per unit area, mean \pm SE, $n=5, P=0.001$ and $P<0.001$, respectively) (Figure 4a).

\section{Figure 4}

Endothelial cell function. (a) VEGF-A-directed migration of wild-type (white bars) and annexin II-deficient (black bars) microvascular endothelial cells across collagen I and fibrin barriers. Shown are mean \pm SE, $n=5$ experiments. (b) Thoracic aortic rings embedded in type I collagen gels and incubated in serum-containing medium for 6 days. Shown are phase-contrast images of branching vessel-like structures in wild-type and annexin II-deficient explants. Scale bar, $0.25 \mathrm{~mm}$. (c) t-PA-dependent plasmin generation in the presence of wild-type (filled circles) versus annexin II-null (open circles) microvascular endothelial cells expressed as relative fluorescence units (RFU). (d) MMP-9 activity in medium conditioned by aortic ring explants from wild-type (white bars) and annexin II-null (black bars) mice in the absence (-PLG) and presence (+PLG) of added plasminogen $(2 \mu \mathrm{g} / \mathrm{ml})$. Shown are mean $\pm \mathrm{SE}, n=6$ experiments. (e) Media from annexin IIdeficient $(\mathrm{KO})$ and wild-type aortic ring explants obtained after culture, analyzed by Western blot using monoclonal anti-MMP-13 IgG and chemiluminescence. The putative active MMP-13 fragment migrates at about $48 \mathrm{kDa}$ and proMMP-13, at about $60 \mathrm{kDa}$. (f) Densitometric analysis of MMP-13 Western blots of medium from cultures of wild-type (white bars) and annexin II-deficient (black bars) aortic rings. Shown are mean $\pm \mathrm{SE}, n=5$ experiments.

\section{Figure 3}

Fibrinolytic function. (a) Plasma clot lysis profiles in the presence $(+)$ and absence (-) of t-PA in wild-type and annexin II-null mice. A, absorbance. (b) Carotid blood flow before and after a 3-minute application of $10 \% \mathrm{FeCl}_{3}\left({ }^{*}\right)$ in wild-type and annexin II-null animals. (c) Maximal arterial occlusion, as \% of initial flow rate, following application of $\mathrm{FeCl}_{3}$ in wild-type and annexin II-null animals (mean $\pm \mathrm{SE}, n=12$ ). (d) Maximal recovery of blood flow over 30 minutes, as \% of initial flow rate, in wild-type and annexin II-null animals (mean $\pm \mathrm{SE}, n=11$ ).

Similarly, collagen I-embedded aortic ring explants from wild-type mice formed robust vessel-like structures, while annexin II-deficient explants formed only rudimentary vessel-like structures (Figure 4b). Compared with that of wild-type explants, the number of vessels emanating from annexin II-null explants was reduced by about $30 \%$ $(18.0 \pm 2.4$ vs. $12.6 \pm 0.8$ vessels per explant, mean $\pm \mathrm{SE}$, $n=6, P<0.001)$ and the frequency of vessel branching, by about $49 \%$ (13.6 \pm 1.6 vs. $7.0 \pm 0.6$ branched vessels per explant, mean $\pm \mathrm{SE}, n=6, P<0.001)$, respectively. Taken together, these data indicate a defect in fibrin and collagen I matrix remodeling in the annexin II-null mouse.

We examined the ability of annexin II-deficient endothelial cells to support t-PA-dependent plasmin generation (Figure 4c). While wild-type cells stimulated plasmin generation dramatically, isolated null cells showed almost no significant t-PA cofactor activity. These data suggested that annexin II is required for endothelial cell surface plasmin generation and its downstream effects.

Because plasmin serves as a direct activator of proMMP-3, and because MMP-3 is a potential activator of proMMP-9 (32), we examined MMP-9 activity in the
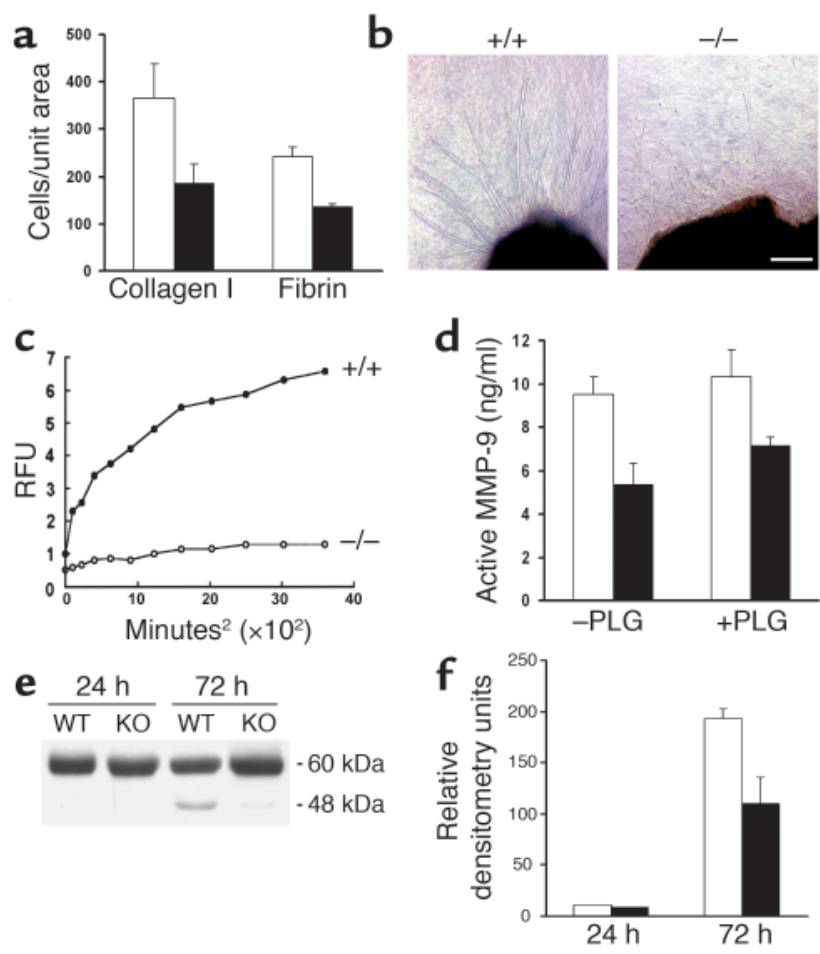
a

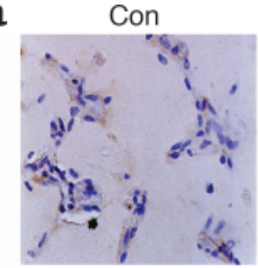

b

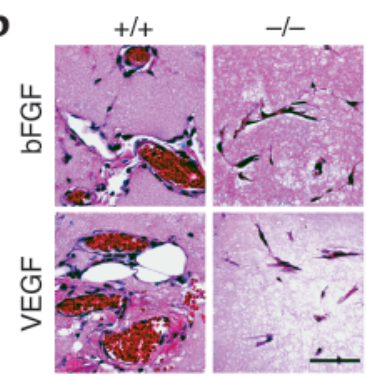

d

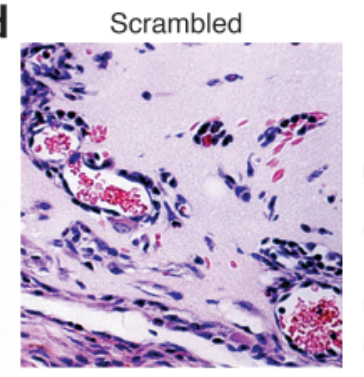

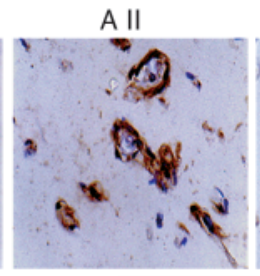

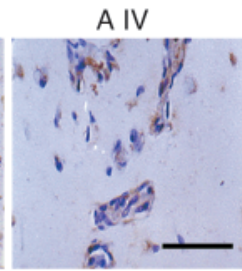

$c$
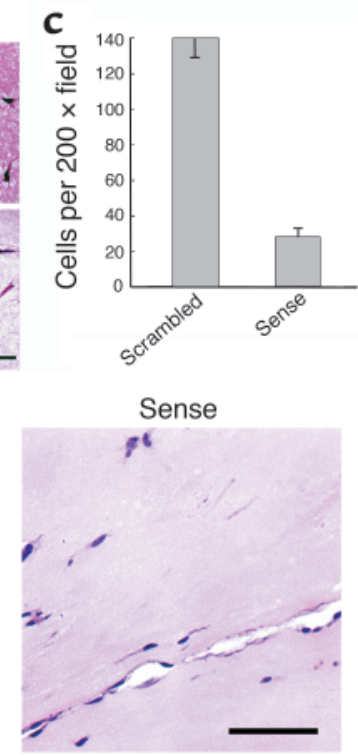

media of collagen I-embedded aortic ring explants obtained after culture. Interestingly, MMP-9 activity was decreased by $45 \%(9.5 \pm 0.8$ vs. $5.4 \pm 1.0 \mathrm{ng} / \mathrm{ml}$, mean $\pm \mathrm{SE}, n=6, P<0.001)$ after 3 days in annexin II-null explant-conditioned medium and corrected only minimally upon the addition of fluid-phase plasminogen $(10.3 \pm 1.3$ vs. $7.1 \pm 0.4 \mathrm{ng} / \mathrm{ml}$, mean $\pm \mathrm{SE}, n=6$, $P<0.001$ ) (Figure $4 \mathrm{~d}$ ). In addition, because MMP-13, a major murine collagenase, is activated by plasmin (33), we analyzed the presence of the active fragment of MMP-13 in aortic ring medium obtained after culture. Again, compared with its activation in wild-type samples, MMP-13 activation was significantly reduced in annexin II-deficient samples (193 \pm 10 vs. $110 \pm 26$ relative units, mean \pm SE, $n=5, P<0.001$ ) (Figure 4 , e and f). These experiments suggest that annexin II-based plasmin deficiency may lead to failure of activation of specific MMPs in the vicinity of the migrating endothe-

\section{Figure 6}

Corneal neoangiogenesis. (a) Neovascular response. Corneas of wildtype and annexin II-null littermates were implanted with pellets containing 0-50 ng bFGF and were photographed on day 5. Original magnification, $\times 75$. (b) Angiogenesis index. The corneal response was quantified for eight eyes at each of five doses of bFGF. (c) Corneal vessel histology. Immunohistochemical analysis of frozen corneal sections stained with anti-fibrin(ogen)/alkaline phosphatase (blue) and anti-PECAM/peroxidase (brown) show partial-thickness fibrin deposition (arrowheads) and vessel-associated endothelial cells (red arrow) in wild-type versus full-thickness fibrin (arrowheads) and isolated endothelial cells (red arrow) in annexin II-deficient corneas. Scale bar, $0.1 \mathrm{~mm}$.

\section{Figure 5}

Neovascularization of Matrigel plugs. (a) Annexin II immunostaining. Matrigel plugs containing VEGF-A $(2 \mu \mathrm{g} / \mathrm{ml})$ were implanted in wildtype mice, harvested on day 12 , and stained with no primary antibody (Con), anti-annexin II (A II) IgG, or anti-annexin IV (A IV) IgG. Scale bar indicates $0.05 \mathrm{~mm}$. (b) Neovascularization in annexin II-deficient mice. Matrigel plugs containing VEGF-A (100 ng/ml) or bFGF (100 $\mathrm{ng} / \mathrm{ml}$ ) were implanted in wild-type and annexin II-deficient mice, harvested on day 12 , fixed, sectioned, and stained with H\&E. Scale bar indicates $0.05 \mathrm{~mm}$. (c) Effect of annexin II N-terminal peptide. Matrigel plugs contained either sense peptide (STVHEILCKLSL; 250 $\mu \mathrm{M})$, mimicking sequences required for t-PA binding to annexin II, or a scrambled control peptide (SLTSVLHKECLI; $250 \mu \mathrm{M}$ ) were analyzed on day 12 by enumeration of cells in sections stained with H\&E (10 random fields per section, 10 sections per sample, four mice per condition). Shown are mean cells per $200 \times$ field (SE; $n=4$ mice). (d) Histological analysis of Matrigel plugs containing scrambled or sense tail peptide (H\&E stain). Scale bar indicates $0.05 \mathrm{~mm}$.

lial cell, thereby retarding cell migration through collagen-containing matrices.

Annexin II deficiency and neoangiogenesis. We next examined the role of annexin II in the formation of new blood vessels in vivo. Neovessels within subcutaneously implanted, VEGF-A-supplemented Matrigel plugs in wild-type mice stained strongly positive for annexin II (Figure 5a). In addition, while Matrigel implants placed in wild-type mice were vascularized with erythrocytecontaining vessel-like structures, those placed in annexin II-deficient animals were nearly devoid of such structures (Figure 5b). Furthermore, inclusion of a peptide that mimics the $\mathrm{N}$-terminal sequence of annexin II (STVHEILCKLSL; sense) and impairs t-PA binding to
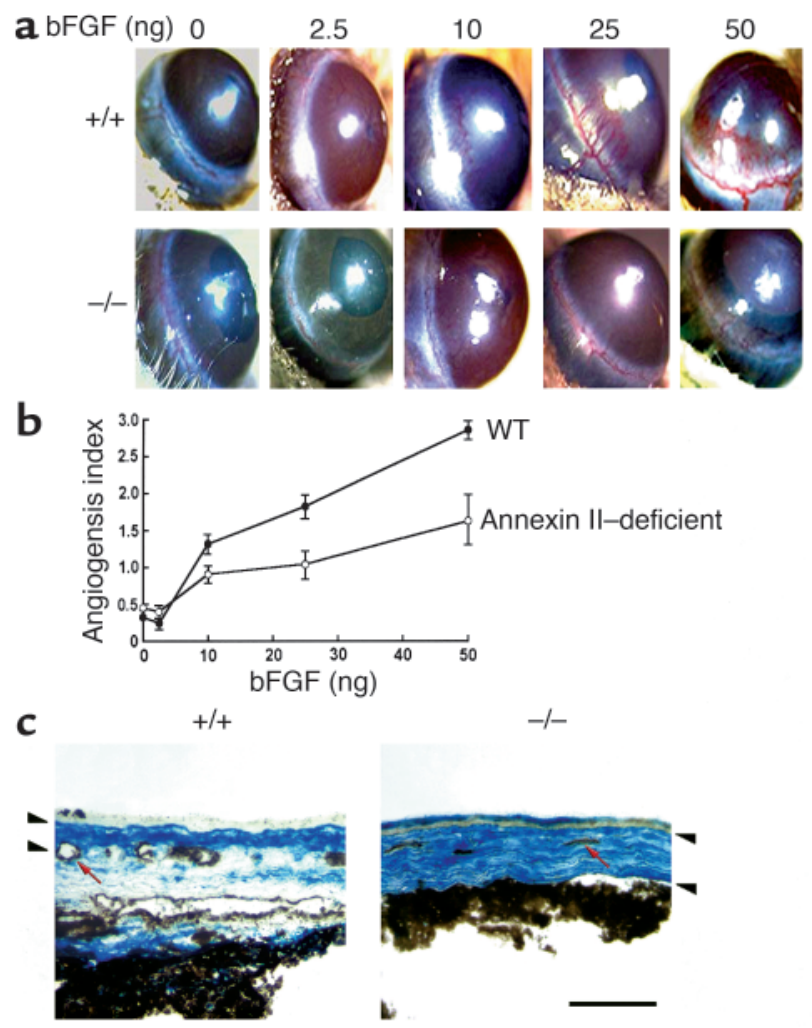
annexin II in vitro (34) was associated with an $80 \%$ decrease in vWF-positive cells compared with that of plugs containing a scrambled control peptide (SLTSVLHKECLI; $140 \pm 14$ vs. $28 \pm 5$ total cells per $200 \times$ field, mean \pm SE, $n=4$ ) (Figure 5c). Histological analysis of the recovered plugs revealed a few scattered cells in the samples containing sense peptide versus a robust neovascular response with numerous erythrocyte-containing neovascular structures in the samples containing scrambled peptide (Figure 5d).

To assess the neovascular response to bFGF, the corneal pocket assay was used (Figure 6). Compared with wild-type controls, annexin II-deficient animals developed fewer, shorter, and less elaborately branching neovessels that occupied a smaller area of the cornea (Figure 6a). The angiogenesis index (30) in annexin II-deficient corneas was reduced by $38-56 \%$ at bFGF concentrations between 10 and $50 \mathrm{ng}$ (Figure 6b). Immunostaining of wild-type corneas revealed fibrin accumulation in the superficial portion of the cornea with numerous PECAM-positive corneal vessels displaying open lumens, while annexin II-null corneas showed full-thickness fibrin deposition and a significant number of isolated endothelial cells that failed to form lumen-containing structures (Figure 6c). These data suggest an impaired neovascular response to sustained bFGF release in the setting of annexin II deficiency.

Retinal neovascularization was examined in an oxygen-induced retinopathy model (Figure 7). While FITCdextran retinography revealed mid-peripheral retinal neovascularization with increased tortuosity of radial vessels emanating from the optic disk in wild-type mice, retinas of oxygen-treated annexin II-null pups were indistinguishable from those of controls treated with room air (Figure 7a). Histological evaluation confirmed that neovascular tufts extending beyond the inner limiting membrane (ILM) and into the vitreal space were present in wild-type controls but were almost entirely absent in annexin II-deficient pups (Figure 7b). Neovascular tufts in wild-type, oxygen-treated retinas showed strong, specific expression of annexin II (Figure

\footnotetext{
Figure 7

Oxygen-induced retinopathy. (a) UV fluorescence images of en face preparations of FITC-dextran-perfused retinas of wild-type $(+/+)$ and annexin II-null (-/-) mice treated with oxygen $\left(\mathrm{O}_{2}\right)$ or maintained in room air (RA). Original magnification, $\times 40$. (b) $\mathrm{H} \& \mathrm{E}$-stained sections of retinas from day-17 wild-type $(+/+)$ versus annexin II-null (-/-) mice showing the absence of a neovascular response in both genotypes maintained in room air and the presence of neoangiogenesis in wild-type (arrows) but not annexin II-deficient mice exposed to high oxygen. Original magnification, $\times 400$. Arrowheads indicate dilated intraretinal blood vessels. (c) Retinal neovascular tufts in wild-type mice induced by high oxygen exposure were stained with anti-annexin II (A II) IgG and isotype-matched anti-annexin IV (A IV) IgG, and counterstained with hematoxylin (original magnification, $\times 1,000$ ). (d) Quantification of vascular nuclei (left panel) and vascular tufts (right panel) located beyond the ILM in retinas of wild-type and annexin II-null newborn mice treated with high oxygen or maintained in room air, at day 17. Shown are mean $\pm \operatorname{SE}(n=4$ experiments $)$.
}

7c). In addition, the number of neovascular nuclei extending beyond the ILM was dramatically reduced in annexin II-deficient animals ( $46.5 \pm 11.8$ vs. $1.0 \pm 0.6$ neovascular nuclei per section, mean $\pm \mathrm{SE}, n=4$, $P<0.001$ (Figure 7d, left panel). Similarly, compared with those of wild-type controls, vascular tufts were strikingly reduced in annexin II-null mice $(8.3 \pm 2.0 \mathrm{vs}$. $1.1 \pm 0.3$ vascular tufts per section, mean $\pm \mathrm{SE}, n=4$, $P<0.001$ ) (Figure $7 \mathrm{~d}$, right panel). Thus, annexin II-null mice were almost completely resistant to oxygeninduced retinal neoangiogenesis.

\section{Discussion}

Although fibrinolytic receptors have been proposed for a number of years, their role in vascular homeostasis has been unclear. In vitro studies of the urokinase receptor (u-PAR), for example, suggested a role in the acceleration of plasmin generation (35), but mice deficient in u-PAR display neither a prothrombotic tendency nor fibrin accumulation in blood vessels or tissues $(36,37)$. Instead, ligation of u-PAR by urokinase appears to regulate integrin function by interacting with molecules of either the $\beta 1\left(\alpha_{3} \beta_{1}\right)(38)$ or the $\beta 2(\mathrm{CD} 11 \mathrm{~b} / \mathrm{CD} 18)$ class, thereby modulating cell-substratum adhesion (39). Here, we have examined the vascular function of mice with complete annexin II deficiency and identified a dual role in both fibrinolytic surveillance and neoangiogenesis.

Annexin II-deficient mice exhibit a number of features previously reported in mice with either plasminogen or combined u-PA/t-PA deficiency. Like mice with
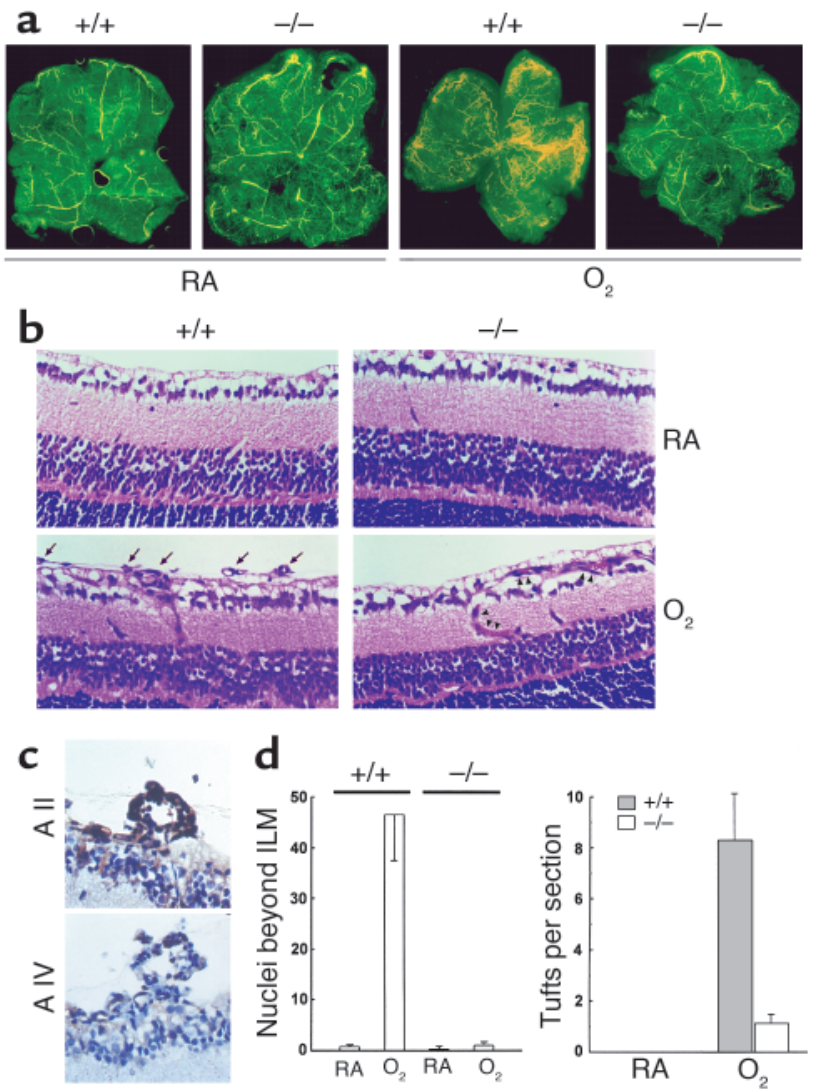
more classic fibrinolytic defects, annexin II-deficient mice displayed normal development, fertility, and lifespan. Physical growth profiles, however, lagged 10-13\% behind those of wild-type controls, just as 20\% and 33\% reductions in body mass have been reported in mice with plasminogen or combined t-PA/u-PA deficiency, respectively $(12,13)$. Similarly, fibrinolytic function, as assessed by fibrin deposition and impaired ability to clear an arterial thrombus, was abnormal in annexin II-null mice, although not to the same degree reported in mice with complete plasminogen or plasminogen activator deficiency. Together, these data suggest that absence of annexin II results in a less dramatic but functionally significant hypofibrinolytic phenotype.

The primary histological feature of annexin II deficiency was the accumulation of fibrin within microvessels in all tissues examined. These deposits were similar to, though less extensive than, those reported in mice with either plasminogen or combined t-PA/u-PA deficiency (11-13). In contrast, mice with isolated t-PA deficiency showed no obvious histological abnormalities in the nonstressed state, while those with u-PA deficiency displayed occasional small focal fibrin deposits (13). Histologically, thus, the annexin II-null phenotype appears to be intermediate in severity between that observed in plasminogen- and t-PA-null mice.

In a more quantitative assessment of fibrin deposition, extractable fibrin was two to three times greater in annexin II-deficient tissues than in wild-type tissues. The literature reports that tissues from mice with isolated t-PA- or u-PA-deficiency display a 10 - to 20 -fold increase in extractable cross-linked fibrin over that in tissues from wild-type mice (26). While these data suggest that the fibrinolytic defect in the annexin II-null animals might be comparatively mild, precise genotypephenotype comparisons would require analysis of tissues from suitably back-crossed animals using the same antibody under identical experimental conditions. Such studies would provide a useful index of the relative roles of annexin II and t-PA in fibrinolytic surveillance in the nonstressed as well as injured state and might conceivably point toward additional, autonomous roles for these two fibrinolytic components.

We report that annexin II deficiency is associated with impaired clearance of injury-induced arterial thrombi. Because others have demonstrated that both t-PA and $\mathrm{u}-$ PA deficiency promote vascular stenosis following ferric chloride-initiated insult (40), it would be of interest to examine the effect of annexin II deficiency in longer-term models of atherosclerosis or vascular fibrosis. While such studies could elucidate a central role for annexin II in the longer-term macrovascular response to injury, the present data reveal its role in fibrinolytic surveillance and establish the endothelial cell surface as a functional component of the vascular fibrinolytic system.

Accumulation of fibrin in knockout tissues could be explained by either accelerated fibrin generation or impaired fibrin clearance. Because plasma recalcification clotting times were identical in samples from the two genotypes, it is unlikely that there are intrinsic differences in fibrinogen function or thrombin activation. Similarly, in vitro plasma clot lysis times were not affected by annexin II deficiency, suggesting that the concentration and functionality of plasma plasminogen, plasminogen activators, and fibrinolytic cofactors or inhibitors were not impaired. However, a defect in cell surface assembly of fibrinolytic molecules would explain the observed delay in thrombolysis within the carotid artery and the accumulation of fibrin plugs within microvessels. Our previous studies have shown that annexin II enhances by 60 -fold the catalytic efficiency by which t-PA, a poor fluid-phase plasminogen activator, can generate plasmin (17). Indeed, our current data show that deficiency of annexin II leads to severe impairment of endothelial cell- and t-PAdependent plasminogen activation, providing a likely explanation for the observed defect in fibrin clearance. Although we observed no effect of annexin II deficiency on endothelial cell proliferation or apoptosis, impairment of directed endothelial cell migration through a collagen I barrier and impairment of endothelial cell migration from collagen I-embedded aortic ring explants were striking features. While fibrin is susceptible to degradation by plasmin, collagen I is not a plasmin substrate. Thus, we considered whether annexin II-bound plasmin might initiate the activation of collagenases not previously considered to be part of the endothelial cell fibrinolytic pathway. The major collagenases in mice are MMP-2, which degrades collagens IV, V, VII, and X; MMP-9 which degrades collagen IV; and MMP-13, which degrades collagens I, II, and III. Of these, only MMP-13 is known to be activated directly by plasmin (33), while MMP-9 can be activated by MMP-3 once it has been activated by plasmin $(32,41)$. Indeed, it is clear from the literature that MMP- 2 is necessary for the neovascularization of malignant melanomas in mice (42); that membrane type $1 \mathrm{MMP}$ mediates vascular invasion of growth plate cartilage (43), the fibroblast growth factor-primed cornea (44), and provisional fibrin matrices $(24,44)$; and that MMP-9 is required for growth plate angiogenesis, possibly through release of VEGF from extracellular matrix $(32,45)$. Thus, when we examined MMP activity, we found significantly reduced levels of active MMP-9 and MMP-13 in medium conditioned by annexin II-deficient aortic ring tissue, compared with medium exposed to wild-type aortic rings. MMP-13 deficiency likely explains the poor migration of annexin II-deficient endothelial cells through a collagen I barrier as well as the impaired outgrowth of capillary-like structures from aortic ring segments embedded in collagen I.

In our study, several experiments revealed a direct role for annexin II in neoangiogenesis in vivo. First, antiannexin II cross-reactive material was strikingly expressed during neovascularization of VEGF-containing Matrigel plugs in wild-type mice. Second, Matrigel plugs implanted in annexin II-deficient mice were poorly vascularized. Finally, when Matrigel plugs 
were supplemented with a peptide that blocks binding of t-PA to annexin II, the endothelial cellularity and overall vascularity of the implanted plug were markedly reduced, suggesting that sequences required for annexin II binding of t-PA are also required for the VEGF-induced angiogenic response in vivo.

In addition, bFGF-induced vascularization of the cornea was markedly reduced in annexin II-deficient animals. Neovessels appearing in the knockout animals were shorter, sparser, and minimally arborized compared with those seen in wild-type controls, and histological studies showed that endothelial cells in the annexin II-deficient corneas were frequently isolated or formed lumenless, cordlike structures. Because the injured corneal stroma is rich in both fibrin $(46,47)$ and multiple isoforms of collagen (types I, VI, and XII) $(48,49)$, impaired breakdown of one or more of these proteins would likely hinder endothelial cell migration and retard the neovascular response.

Finally, the neovascular response to oxygen stimulation was severely impaired in the neonatal retina in the setting of annexin II deficiency. In this model, angiogenesis appears to be driven by VEGF (50), as it can be inhibited by VEGF receptor antagonists (51), by VEGF antisense oligonucleotides (52), or by soluble VEGF receptor protein (53). In the normal angiogenic response, neovascular endothelial cells migrate from the retina and penetrate the ILM, a structure composed primarily of collagen fibers and glycosaminoglycans (54) that forms the boundary between the vitreous and retina (31). Our data show that ILM-penetrating retinal neovessels exhibit robust expression of annexin II after induction with oxygen and fail to form in the absence of annexin II. Together, these findings demonstrate that annexin II plays a central, matrix-remodeling role in the collagen-rich, fibrin-free environment of the neonatal retina.

Plasmin may promote angiogenesis through several mechanisms (55). Plasmin may release bFGF sequestered within extracellular matrix (56) and activate transforming growth factor- $\beta$ (57), a potent antiproliferative, proinvasive endothelial cell-differentiating factor (58). Plasmin may attenuate fibrin-mediated endothelial cell adhesion via $\alpha_{v} \beta_{3}$ integrin (59), and plasmin-derived fibrin degradation products may stimulate endothelial cell proliferation (60). Plasmin may degrade nonfibrin substrates such as laminin, fibronectin, and the protein core of proteoglycans, but not elastin or native helical collagen $(61,62)$. Plasmin may regulate vascular-endothelial cell cadherin-mediated cell self-association $(63,64)$ or signal new programs of gene expression that promote neoangiogenesis (65, $66)$. Our data provide a novel mechanism whereby plasmin can be generated specifically at the cell surface through the action of annexin II-bound plasminogen and tissue plasminogen activator. The findings suggest further that annexin II-bound endothelial cell surface plasmin may act not only intravascularly to maintain blood vessel patency but also extravascularly to promote endothelial cell migration through fibrin and collagen matrices, via activation of key MMPs. Thus, annexin II-mediated plasmin generation at the cell surface may support two closely related processes, namely fibrinolytic surveillance and neoangiogenesis.

\section{Acknowledgments}

This work was supported by grants from the NIH (HL 67839, HL 42493, and HL 46403 to K.A. Hajjar). A.T. Jacovina was supported by NIH training grant HL 07423. We thank Ralph L. Nachman for insightful discussions; David Loskutoff and Stavros Konstantinides for assistance with the carotid thrombosis model; David C. Lyden and Shahin Rafii for their critical review of the manuscript; and Scott A. Kerns for assistance with the preparation of the figures.

1. Cines, D.B., et al. 1998. Endothelial cells in physiology and in the pathophysiology of vascular disorders. Blood. 91:3527-3561.

2. Hajjar, K.A., Esmon, N.L., Marcus, A.J., and Muller, W.A. 2001. Vascular function in hemostasis. In Williams hematology. E. Beutler, M.A. Lichtman, B.S. Coller, T.J. Kipps, and U. Seligsohn, editors. McGraw-Hill. New York, New York, USA. 1451-1469.

3. Jalbert, L.R., et al. 1998. Inactivation of the gene for anticoagulant protein $\mathrm{C}$ causes lethal perinatal consumptive coagulopathy in mice. J. Clin. Invest. 102:1481-1488.

4. Enjyoji, K., et al. 1999. Targeted disruption of CD39/ATP diphosphohydrolase results in disordered hemostasis and thromboregulation. Nat. Med. 5:1010-1017.

5. Semeraro, N., and Colucci, M. 1997. Tissue factor in health and disease. Thromb. Haemost. 78:759-764.

6. Hajjar, K.A. 2000. Molecular mechanisms of fibrinolysis. In Williams hematology. E. Beutler, M.A. Lichtman, B.S. Coller, T.J. Kipps, and U. Seligsohn, editors. McGraw-Hill. New York, New York, USA. 1479-1493.

7. Hajjar, K.A. 1998. The molecular basis of fibrinolysis. In Hematology of infancy and childhood. D.G. Nathan, and Orkin, S.H., editors. W.B. Saunders Co. Philadelphia, Pennsylvania, USA. 1557-1573.

8. Levin, E.G., and del Zoppo, G.J. 1994. Localization of tissue plasminogen activator in the endothelium of a limited number of vessels. Am. J. Pathol. 144:855-861.

9. Levin, E.G., Santell, L., and Osborn, K.G. 1997. The expression of endothelial tissue plasminogen activator in vivo: a function defined by vessel size and anatomic location. J. Cell Sci. 110:139-148.

10. Rosenberg, R.D., and Aird, W.C. 1999. Vascular-bed-specific hemostasis and hypercoagulable states. N. Engl. J. Med. 340:1555-1564.

11. Bugge, T.H., Flick, M.J., Daugherty, C.C., and Degen, J.L. 1995. Plasminogen deficiency causes severe thrombosis but is compatible with development and reproduction. Genes Dev. 9:794-807.

12. Ploplis, V.A., et al. 1995. Effects of disruption of the plasminogen gene on thrombosis, growth, and health in mice. Circulation. 92:2585-2593.

13. Carmeliet, P., et al. 1994. Physiological consequences of loss of plasminogen activator gene function in mice. Nature. 368:419-424.

14. Drew, A.F., et al. 1998. Ligneous conjunctivitis in plasminogen-deficient mice. Blood. 91:1616-1624.

15. Schott, D., et al. 1998. Therapy with a purified plasminogen concentrate in an infant with ligneous conjunctivitis and homozygous plasminogen deficiency. N. Engl. J. Med. 339:1679-1686.

16. Hajjar, K.A., Jacovina, A.T., and Chacko, J. 1994. An endothelial cell receptor for plasminogen and tissue plasminogen activator: I. Identity with annexin II. J. Biol. Chem. 269:21191-21197.

17. Cesarman, G.M., Guevara, C.A., and Hajjar, K.A. 1994. An endothelial cell receptor for plasminogen/tissue plasminogen activator: II. Annexin IImediated enhancement of t-PA-dependent plasminogen activation. J. Biol. Chem. 269:21198-21203.

18. Ishii, H., et al. 2001. Recombinant annexin II modulates impaired fibrinolytic activity in vitro and in rat carotid artery. Circ. Res. 89:1240-1245.

19. Menell, J.S., et al. 1999. Annexin II and bleeding in acute promyelocytic leukemia. N. Engl. J. Med. 340:994-1004.

20. Nagashima, M., et al. 2002. Thrombin-activatable fibrinolysis inhibitor (TAFI) deficiency is compatible with murine life. J. Clin. Invest. 109:101-110.

21. Konstantinides, S., Schafer, K., Koschnick, S., and Loskutoff, D.J. 2001. Leptin-dependent platelet aggregation and arterial thrombosis suggests a mechanism for atherothrombotic disease in obesity. J. Clin. Invest. 108:1533-1540.

22. Lodge, P.A., Haisch, C.E., and Thomas, F.T. 1992. A simple method of vascular endothelial cell isolation. Transplant. Proc. 24:2816-2817.

23. Jacovina, A.T., et al. 2001. Neuritogenesis and the nerve growth factor- 
induced differentiation of PC-12 cells requires annexin II-mediated plasmin generation. J. Biol. Chem. 276:49350-49358.

24. Hiraoka, N., Allen, E., Apel, I.J., Gyetko, M.R., and Weiss, S.J. 1998. Matrix metalloproteinases regulate neovascularization by acting as pericellular fibrinolysins. Cell 95:365-377.

25. Devy, L., et al. 2002. The pro- or antiangiogenic effect of plasminogen activator inhibitor 1 is dose dependent. FASEB J. 16:147-154.

26. Weiler-Guettler, H., et al. 1998. A targeted point mutation in thrombomodulin generates viable mice with a prethrombotic state. J. Clin. Invest. 101:1983-1991.

27. Christie, P.D., et al. 1999. A murine model of myocardial microvascular thrombosis. J. Clin. Invest. 104:533-539.

28. Passaniti, A., et al. 1992. A simple, quantitative method for assessing angiogenesis and antiangiogenic agents using reconstituted basement membrane, heparin, and fibroblast growth factor. Lab. Invest. 67:519-528.

29. Kenyon, B.M., et al. 1996. A model of angiogenesis in the mouse cornea. Invest. Ophthalmol. Vis. Sci. 37:1625-1632.

30. Kenyon, B.M., Browne, F., and D’Amato, R.J. 1997. Effects of thalidomide and related metabolites in a mouse corneal model of neovascularization. Exp. Eye Res. 64:971-978.

31. Smith, L.E.H., et al. 1994. Oxygen-induced retinopathy in the mouse. Invest. Ophthalmol. Vis. Sci. 35:101-111.

32. Ramos-DeSimone, N., et al. 1999. Activation of matrix metalloproteinase-9 (MMP-9) via a converging plasmin/stromelysin-1 cascade enhances tumor cell invasion. J. Biol. Chem. 274:13066-13076.

33. Netzel-Arnett, S., et al. 2002. Collagen dissolution by keratinocytes requires cell surface plasminogen activation and matrix metalloproteinase activity. J. Biol. Chem. 277:45154-45161.

34. Hajjar, K.A., et al. 1998. Tissue plasminogen activator binding to the annexin II tail domain: direct modulation by homocysteine. J. Biol. Chem. 273:9987-9993

35. Roldan, A.L., et al. 1990. Cloning and expression of the receptor for human urokinase plasminogen activator, a central molecule in cell surface, plasmin-dependent proteolysis. EMBOJ. 9:467-474

36. Bugge, T.H., et al. 1995. The receptor for urokinase-type plasminogen activator is not essential for mouse development or fertility.J. Biol. Chem 270:16886-16894.

37. Dewerchin, M., et al. 1996. Generation and characterization of urokinase receptor-deficient mice. J. Clin. Invest. 97:870-878.

38. Wei, Y., Eble, J.A., Wang, Z., Kreidberg, J.A., and Chapman, H.A. 2001 Urokinase receptors promote $\beta 1$ integrin function through interactions with integrin $\alpha 331$. Mol. Biol. Cell 12:2975-2986.

39. Simon, D.I., et al. 2000. Identification of a urokinase receptor-integrin interaction site: promiscuous regulator of integrin function. J. Biol. Chem. 275:10228-10234.

40. Schafer, K., et al. 2002. Different mechanisms of increased luminal stenosis after arterial injury in mice deficient for urokinase- or tissuetype plasminogen activator. Circulation. 106:1847-1852.

41. Loskutoff, D.J., and Quigley, J.P. 2000. PAI-1, fibrosis, and the elusive provisional fibrin matrix. J. Clin. Invest. 106:1441-1443.

42. Itoh, T., et al. 1997. Reduced angiogenesis and tumor progression in gelatinase A-deficient mice. Cancer Res. 58:1048-1051.

43. Holmbeck, K., et al. 1999. MT1-MMP-deficient mice develop dwarfism, osteopenia, arthritis, and connective tissue disease due to inadequate collagen turnover. Cell. 99:82-92.

44. Zhou, Z., et al. 2000. Impaired endochondral ossification and angiogenesis in mice deficient in membrane-type metalloproteinase. Proc. Natl. Acad. Sci. U. S. A. 97:4052-4057.

45. Vu, T., et al. 1998. MMP-9/Gelatinase B is a key regulator of growth plate angiogenesis and apoptosis of hypertrophic chondrocytes. Cell. 93:411-422.

46. Kao, W.W.Y., et al. 1998. Healing of corneal epithelial defects in plasminogen- and fibrinogen-deficient mice. Invest. Ophthalmol. Vis. Sci. 39:502-508.
47. Drew, A.F., et al. 2000. Persistent corneal haze after excimer laser photokeratectomy in plasminogen-deficient mice. Invest. Ophthalmol. Vis. Sci. 41:67-72.

48. Leung, E.W., Rife, L., Smith, R.E., and Kay, E.P. 2000. Extracellular matrix components in retrocorneal fibrous membrane in comparison to corneal endothelium and Descemet's membrane. Mol. Vision. 6:15-23.

49. Hirsch, M., Prenant, G., and Renard, G. 2001. Three-dimensional supramolecular organization of the extracellular matrix in human and rabbit corneal stroma, as revealed by ultrarapid-freezing and deep-etching methods. Exp. Eye Res. 72:123-135.

50. Pierce, E.A., Avery, R.L., Foley, E.D., Aiello, L.P., and Smith, L.E.H. 1995. Vascular endothelial growth factor/vascular permeability factor expression in a mouse model of retinal neovascularization. Proc. Natl. Acad. Sci. U. S. A. 92:905-909.

51. Ozaki, H., et al. 2000. Blockade of vascular endothelial cell growth factor receptor signaling is sufficient to completely prevent retinal neovascularization. Am. J. Pathol. 156:697-707.

52. Robinson, G.S., et al. 1996. Oligodeoxynucleotides inhibit retinal neovascularization in a murine model of proliferative retinopathy. Proc. Natl. Acad. Sci. U. S. A. 93:4851-4856.

53. Aiello, L.M., et al. 1995. Suppression of retinal neovascularization in vivo by inhibition of vascular endothelial growth factor (VEGF) using soluble VEGF-receptor chimeric proteins. Proc. Natl. Acad. Sci. U. S. A 921:10457-10461.

54. Heegaard, S., Jensen, O.A., and Prause, J.U. 1986. Structure and composition of the inner limiting membrane of the retina. Graefe's Arch. Clin. Exp. Ophthalmol. 224:355-360.

55. Browder, T., Folkman, J., and Pirie-Shepherd, S. 2000. The hemostatic system as a regulator of angiogenesis. J. Biol. Chem. 275:1521-1524.

56. Falcone, D.J., McCaffrey, T.A., Haimovitz-Friedman, A., Vergilio, J.A., and Nicholson, A.C. 1993. Macrophage and foam cell release of matrixbound growth factors. Role of plasminogen activation. J. Biol. Chem. 268:11951-11958.

57. Lyons, R.M., Gentry, L.E., Purchio, A.F., and Moses, H.L. 1990. Mechanism of activation of latent recombinant transforming growth factor $\beta 1$ by plasmin. J. Cell Biol. 110:1361-1367.

58. Sporn, M.B., Roberts, A.B., Wakefield, L.M., and Assoian, R.K. 1986. Transforming growth factor- $\beta$ : Biological function and chemical structure. Science. 233:532-534.

59. Thiagarajan, P., Rippon, A.J., and Farrell, D.H. 1996. Alternative adhesion sites in human fibrinogen for vascular endothelial cells. Biochemistry. 35:4169-4175.

60. Thompson, W.D., et al. 1992. Angiogenic activity of fibrin degradation products is located in fibrin fragment E. J. Pathol. 168:47-53.

61. Chen, Z.L., and Strickland, S.E. 1997. Neuronal death in the hippocampus is promoted by plasmin-catalyzed degradation of laminin. Cell. 91:917-925.

62. Werb, Z., Banda, P.A., and Jones, P.A. 1980. Degradation of connective tissue matrices by macrophages: I. Proteolysis of elastin, glycoproteins and collagen by proteinases isolated from macrophages. J. Exp. Med. 152:1340-1357.

63. Bach, T.L., Barsigian, C., Yaen, C.H., and Martinez, J. 1998. Endothelial cell VE-cadherin functions as a receptor for the $\beta 15-42$ sequence of fibrin. J. Biol. Chem. 273:30719-30728.

64. Bach, T.L., et al. 1998. VE-Cadherin mediates endothelial cell capillary tube formation in fibrin and collagen gels. Exp. Cell Res. 238:324-334

65. Pendurthi, U.R., Ngyuen, M., Andrade-Gordon, P., Petersen, L.C., and Rao, L.V.M. 2002. Plasmin induces Cyr61 gene expression in fibroblasts via protease-activated receptor-1 and $\mathrm{p} 44 / 42$ mitogen-activated protein kinase-dependent signalling pathway. Arterioscler. Thromb. Vasc. Biol. 22:1421-1426.

66. Tarui, T., Majumdar, M., Miles, L.A., Ruf, W., and Takada, Y. 2002. Plasmin-induced migration of endothelial cells. J. Biol. Chem. 277:33564-33570. 